\title{
Rubiacearum Americanarum Magna Hama Pars XXVII: Six New Species and a New Taxonomic View of Posoqueria
}

\author{
Charlotte M. Taylor \\ Missouri Botanical Garden, P.O. Box 299, St. Louis, Missouri 63166-0299, U.S.A. Author for \\ correspondence: charlotte.taylor@mobot.org
}

Barry Hammel

Missouri Botanical Garden, P.O. Box 299, St. Louis, Missouri 63166-0299, U.S.A., and Instituto Nacional de Biodiversidad (INBio), Apdo. 22-3100, Santo Domingo, Heredia, Costa Rica.

barry.hammel@mobot.org

Roy E. Gereau

Missouri Botanical Garden, P.O. Box 299, St. Louis, Missouri 63166-0299, U.S.A.

roy.gereau@mobot.org

Abstract. The Neotropical genus Posoqueria Aubl. (Rubiaceae) has a number of species with an asymmetric androecium and pollen catapult mechanism and others that apparently lack these features. A new taxonomy based on corolla form and size, the length and symmetry of the filaments, and fruit morphology finds the name $P$. panamensis (Walp. \& Duchass.) Walp. to be a synonym of $P$. latifolia (Rudge) Roem. \& Schult. and distinguishes additional species in southern Central America and northwestern South America, newly described here: P. chocoana C. M. Taylor of wet lowland Panama to northwestern Ecuador has medium-sized corollas, subglobose fruits, corolla lobes of unequal size, and a generally symmetric androecium that apparently lacks the pollen catapult mechanism; $P$. correana C. M. Taylor of lowland and premontane Panama has medium-sized corollas, leaf blades that are sharply acute at the apex and densely velutinous abaxially, slightly unequal corolla lobes, and a generally symmetric androecium that apparently lacks the pollen catapult mechanism; P. costaricensis C. M. Taylor, found in premontane forests in Costa Rica and Panama, has relatively short corollas (for Posoqueria) and a generally symmetric androecium that apparently lacks the pollen catapult mechanism; P. grandifructa Hammel \& C. M. Taylor of lowland Nicaragua and Costa Rica has medium-sized corollas, relatively large, ellipsoid, rough-surfaced, thickwalled fruits, and a generally symmetric androecium that apparently lacks the pollen catapult mechanism; $P$. longifilamentosa C. M. Taylor of lowland northwestern Ecuador has relatively long corollas and an asymmetric androecium with a pollen catapult mechanism, relatively long unequal filaments, and relatively large anthers; and $P$. robusta Hammel \& C. M. Taylor of lowland Nicaragua and Costa Rica has leathery leaves, relatively long corollas with unequal lobes, subglobose leathery fruits, and a symmetric androecium that apparently lacks the pollen catapult mechanism.

Resumen. El género neotropical Posoqueria Aubl. (Rubiaceae) incluye varias especies con androceo asimétrico y un mecanismo de dispersión del polen por catapulta, y varias especies sin estes carácteres. Una taxonomía nueva basada en la forma y el tamaño de la corola, el largo y la simetría de los filamentos y la morfología de los frutos demuestra que el nombre P. panamensis (Walp. \& Duchass.) Walp. es sinónimo de P. latifolia (Rudge) Roem. \& Schult., y distingue otras especies en el sur de América Central y el noroeste de América del Sur, nuevamente descritas aquí: $P$. chocoana C. M. Taylor de tierra baja húmeda de Panamá al noroeste de Ecuador tiene corolas de tamaño mediano, frutos subglobosos y los lobos de la corola de tamaño desigual, además un androceo por lo general simétrico que aparentemente no tiene el mecanismo de catapulta de polen; $P$. correana C. M. Taylor de tierra baja y premontana de Panamá tiene corolas de tamaño mediano, hojas con la lámina muy aguda en el ápice y densamente velútina en el envés, lobos de la corola un poco desiguales y un androceo por lo general simétrico que aparentemente no tiene el mecanismo de catapulta de polen; $P$. costaricensis C. M. Taylor, de bosques premontanos en Costa Rica y Panamá, tiene corolas relativamente cortas (para Posoqueria) y un androceo por lo general simétrico que aparentemente no tiene el mecanismo de 
catapulta de polen; $P$. grandifructa Hammel \& C. M. Taylor de tierra baja de Nicaragua y Costa Rica tiene corolas de tamaño mediano, frutos relativamente grandes, elipsoides, de superficie tosca y de pared gruesa y un androceo por lo general simétrico que aparentemente no tiene el mecanismo de catapulta de polen; $P$. longifilamentosa C. M. Taylor de tierra baja de Ecuador tiene corolas relativamente largas, un androceo asimétrico con un mecanismo de catapulta de polen, filamentos relativamente largos y desiguales y anteras relativamente grandes; y $P$. robusta Hammel \& C. M. Taylor de tierra baja de Nicaragua y Costa Rica tiene hojas coriáceas, corolas relativamente largas con los lobos desiguales, subglobosos frutos coriáceos y un androceo simétrico que aparentemente no tiene el mecanismo de catapulta de polen.

Key words: Colombia, Costa Rica, Ecuador, Henriquezieae, IUCN Red List, Ixoroideae, Nicaragua, Panama, pollination biology, Posoqueria, Posoquerieae, Rubiaceae.

The Neotropical genus Posoqueria Aubl. (Rubiaceae) includes about 25 species of shrubs and small to medium-sized trees found in wet lowland to montane vegetation and in gallery and scrub forest from Mexico through to Bolivia and southern Brazil. Posoqueria is notable for its white salverform corollas with very prolonged slender tubes, up to $36 \mathrm{~cm}$ long and generally only $2-4 \mathrm{~mm}$ diam. The genus is characterized by its woody habit; its ovate to elliptic stipules that are interpetiolar or sometimes very shortly united around the stem, held erect and backto-back in bud, and usually quickly deciduous from the stems; its terminal, shortly cymose inflorescences with the bracts small or sometimes only irregularly developed; its pedicellate, homostylous, showy flowers; its notably long slender corollas with the five lobes that are imbricate in bud; its five anthers that are dorsifixed near the base on short to welldeveloped filaments and have a short, generally triangular sterile projection of the thecae on each end (Puff et al., 1995); its completely or occasionally incompletely 2-locular ovary with the numerous ovules borne on axile placentas; and its welldeveloped, baccate, often rather thick-walled fruits generally $3-13 \mathrm{~cm}$ long and with several broadly angled smooth seeds, generally $1-1.5 \mathrm{~cm}$ long, immersed in the fleshy, mealy, or gelatinous pulp. The flowers are nocturnal and fragrant, and pollinated by sphingid moths (Bawa \& Beach, 1983; Beach, 1983). Delprete (2009) noted that the corolla lobes may sometimes be convolute; this was also reported by Burger and Taylor (1993), but has not been reconfirmed and may be based on incomplete observations of the imbricate arrangement. The most common and widespread species is $P$. latifolia (Rudge) Roem. \& Schult., which is also occasionally cultivated as an ornamental. The relationships of Posoqueria have long been unclear, but recent molecular data have clarified its position in the subfamily Ixoroideae. It has been included in the tribe Posoquerieae by Delprete et al. (2004) and Delprete (2009), and in the Henriquezieae subtribe Posoqueriinae by Robbrecht and Manen (2006). Molecular data have indicated that Posoqueria is related to Molopanthera Turcz., with these two genera together sister to Gleasonia Standl. and Sipanea Aubl. (Rova et al., 2002; Platycarpum Bonpl. was not included in their analysis), and also that Posoqueria is related to Platycarpum and Sipanea (Cortés et al., 2009; Gleasonia and Molopanthera were not included in their analysis).

A notable feature of many Posoqueria species is the asymmetric androecium with a characteristic catapult mechanism of pollen dispersal. This mechanism has been described in detail by several authors including Hutchinson (1915), Beach (1983), and Puff et al. (1995), and was recently summarized also by Delprete (2009), who illustrated in detail the characteristic unequal stamen filaments. In these Posoqueria flowers, the two dorsal stamens have the longest filaments, the two lateral stamens have filaments of intermediate length, and the ventral filament is the shortest; the anthers are of similar size and variously glabrescent to puberulous, pilosulose, and/or pilose in tufts. When the corolla first opens, the introrse anthers are weakly united into an ellipsoid structure (Hutchinson, 1915: fig. 100; Puff et al., 1995: fig. 13; Delprete, 2009: figs. 3, 4) by the fusion of the epidermis of the sterile appendages (Puff et al., 1995), and this anther group is held erect directly over the mouth of the corolla tube. In this arrangement, the shortest filament is straight while the other filaments curve to accommodate their greater length, and all of the filaments are apparently under tension. The pollen is released at this stage (Hutchinson, 1915) in one or several clumps, but remains inside this ellipsoid anther group until one of the filaments is bumped by a pollinator, which triggers an explosive separation of the anthers and catapults the pollen "out to some distance" (Hutchinson, 1915: 306). In this action, the four anthers with the longer filaments move to a reflexed position, so these anthers are positioned with their dorsal side lying on or near the corolla lobes, while the shortest filament is flexed forward and its anther positioned to cover the mouth of the corolla tube. After about half a 
day (Hutchinson, 1915: 306), the shortest filament changes to a reflexed position so its anther is then also positioned with its dorsal side lying on the remaining corolla lobe, and the corolla tube is again accessible to pollinators. The presence of the unequal filaments and this catapult mechanism is evident even when the flower is in bud, because the unequal filaments in part make the lobe portion of the corolla bud bent or deflected at about $30^{\circ}-45^{\circ}$ in relation to its tube (Delprete, 2009: fig. 3A). Similar asymmetric stamens, sterile anther appendages, and a pollen catapult mechanism are found in the monotypic genus Molopanthera of southeastern Brazil (Delprete, 2009), which appears to be closely related to Posoqueria. Additionally, in Posoqueria flowers the corolla lobes are often unequal in length, by as much as $30 \%$, with one longest, two or three of medium length, and one or two of the shortest length. These unequal corolla lobes have not been detailed by previous taxonomic studies of this genus, probably at least in part due to most of those observations being based on dried herbarium specimens where unequal corolla lobe length may be an artifact of specimen preparation. The unequal size of the corolla lobes is evident in the corolla bud, and also makes the lobe portion of the corolla bud deflect or bend.

However, as noted by Delprete (2009), not all species of Posoqueria have an evidently asymmetric androecium or apparently the pollen catapult mechanism. These other Posoqueria species have anthers that are also borne in a coherent or weakly fused, ellipsoid group that is held erect in the center of the flower on filaments of equal or nearly equal length, with the anthers later separating and spreading and the filaments becoming slightly curved. However, in these species the filaments are generally straight in bud and generally equal in length (Taylor \& CortésBallén, 1999: fig. 1; Macias \& Kinoshita, 2003: fig. 1), and in contrast to the species with an asymmetric androecium, their anthers are partially included in the corolla tube or just barely fully exserted from it (i.e., with the base of the anther positioned less than 1 $\mathrm{mm}$ above the top of the corolla tube). In these species, the lobe portion of the corolla bud is generally straight with respect to the tube, although in some of these species the corolla lobes are also unequal in size, so the corolla buds have the lobe portion bent or deflexed but usually only to $10^{\circ}-20^{\circ}$ with respect to the corolla tube.

Posoqueria has been studied taxonomically only regionally, with the exception of one study that has apparently not been published (Macias, 1988, unpublished thesis). Steyermark (1967) presented the general taxonomic concepts and species circum- scriptions in use until now in Central America and northern South America, and he noted that Posoqueria was very poorly known and his observation is still accurate. Steyermark distinguished the Posoqueria species of northern South America and southern Central America based primarily on form and distribution of the pubescence of the leaves, corollas, and anthers. He circumscribed several species that included notably broad ranges of corolla size, such as P. coriacea M. Martens \& Galeotti, with the corolla tubes 8.5-29 cm long, and P. panamensis (Walp. \& Duchass.) Walp. with the corolla tubes $12.5-25 \mathrm{~cm}$ long (Steyermark, 1967). He also circumscribed species of Posoqueria to include plants with an asymmetric androecium, bent corolla buds, and the pollen catapult mechanism together with plants that lack these features. Steyermark noted variation in these androecium features, but considered all the flowers with short straight filaments and an actinomorphic androecium to be immature with the unequal filaments simply not yet expanded (1967:329), rather than recognizing that the flowers were mature and different. Steyermark stated that this conclusion was based on Hutchinson's figure (1915: fig. 100); however, that figure clearly shows the developed, curving filaments of flowers with the catapult mechanism, rather than the short straight filaments of the flowers with the actinomorphic androecium. Since Steyermark's work, Posoqueria has been said to comprise species that all have an asymmetric androecium, or to include only one (Delprete, 2009) or a few (Macias, 1988) exceptional species with an actinomorphic androecium. However, as documented here, at least nine species of Posoqueria have an actinomorphic androecium without the pollen catapult mechanism and corolla buds with the lobe portion generally straight with respect to the tube. Presence versus absence of an asymmetric androecium and catapult pollination mechanism separates two groups of species: a set of species with a clearly asymmetric androecium, including $P$. acutiflora Mart., P. coriacea, P. grandiflora Standl., P. latifolia, P. longifilamentosa C. M. Taylor, P. longiflora Aubl., $P$. maxima Standl., P. palustris Mart., $P$. trinitatis DC., and $P$. williamsii Steyerm.; and a set of species with an actinomorphic androecium and apparently without the pollen catapult mechanism, including $P$. bahiensis Macias \& Kin.-Gouv., P. chocoana C. M. Taylor (described in this article), P. correana C. M. Taylor (described in this article), P. costaricensis C. M. Taylor (described in this article), P. grandifructa Hammel \& C. M. Taylor (described in this article), $P$. laevis C. M. Taylor, P. mutisii Standl., P. robusta 
Hammel \& C. M. Taylor (described in this article), and P. tarairensis C. M. Taylor \& Cortés-Ballén.

Steyermark (1967) distinguished several species of Posoqueria based on the density and form of the pubescence on the anthers, and in some cases based also on the pubescence of basal appendages of the anthers. However, with more flowering collections available today, continuous variation in these features can be seen within several species, and Macias (1988) did not distinguish species based on anther characters. Steyermark also noted discontinuous variation in the length of the corolla tube, but considered corolla length to indicate varieties within a species rather than to characterize species. However, with more collections available now, a pattern is evident in corolla length, and this feature does seem to characterize species. In general, Posoqueria species with relatively small flowers, i.e., with the corolla tubes generally $6.5-12 \mathrm{~cm}$ long, are found in premontane, montane, dry, seasonal, and gallery forests (e.g., P. bahiensis, P. coriacea, P. tarairensis); species with medium-sized flowers, with the corolla tubes generally $12-20 \mathrm{~cm}$ long, are found in lowland to premontane wet forests (e.g., $P$. chocoana, P. grandifructa, P. latifolia); and species with relatively long flowers, with corolla tubes generally $22-36 \mathrm{~cm}$ long, are found in wet lowland forests (e.g., P. grandiflora, P. longifilamentosa, P. maxima, $P$. williamsii).

Steyermark (1967) did not consider the fruits to differ in form among Posoqueria species, or at least did not regard this variation as characterizing different species, and did not even mention fruit characters in his classification. In part this was no doubt due to the difficulty of matching fruiting and flowering specimens in this genus. Macias (1988) similarly gave little descriptive detail of the fruits and did not use them to distinguish any species. However, field observations show that in at least some cases Posoqueria species are characterized by differences among their fruits as well as their flowers. Fruit characters are thus incorporated into the new taxonomy presented here.

\section{Notes on POSOQUeria Panamensis and P. CORIACEA}

Steyermark (1967) included many plants from Central America and northern South America in Posoqueria panamensis (Walp. \& Duchass.) Walp. He distinguished $P$. panamensis by its stipules $9-32 \mathrm{~mm}$ long, its firmly chartaceous to sometimes subcoriaceous leaves, its corolla tubes $12.5-25 \mathrm{~cm}$ long, and its anthers that are densely papillate to glabrous, from P. latifolia with its stipules $3-14 \mathrm{~mm}$ long, usually thickly coriaceous leaves, its corolla tubes $4-12 \mathrm{~cm}$ long, and its anthers that are glabrous to papillate. In Steyermark's circumscription, $P$. panamensis was a widespread heterogeneous species that was difficult to characterize morphologically or ecologically. Subsequent authors either synonymized $P$. panamensis with P. latifolia (Dwyer, 1980) or followed Steyermark's taxonomy and applied the name $P$. panamensis to all Posoqueria plants with rather large corollas and leaves that are not shiny on the adaxial surface when dry (Burger \& Taylor, 1993; Taylor, 2001; Taylor et al., 2004; L. Macias in herb.). The name $P$. panamensis was based on a plant from Panama that has not been traced as a specimen or a figure, but can be interpreted based on the description in the protologue. This described the corolla buds as having the lobe portion bent and gibbous and the filaments well developed and of unequal length, as well as hooked at the apex: this description indicates that $P$. panamensis has flowers with an asymmetric androecium and pollen catapult mechanism, which produce the bent attitude of the lobe portion of the corolla bud; a bent or hooked apex is sometimes found on the old, reflexed filaments of Posoqueria species that have the pollen catapult mechanism. Additionally, the protologue describes $P$. panamensis as having shiny leaves and a corolla tube ca. $10 \mathrm{~cm}$ long. In the classification here of Central American Posoqueria, two species with an asymmetric androecium, shiny leaves, and corolla tubes of this size are known from Panama today: $P$. coriacea is rare in montane forests, and P. latifolia is widespread and common, both in the wild and cultivated, in lowland central Panama including in the Canal Zone, which is the most likely type locality for this name. The name $P$. panamensis is, therefore, here considered a synonym of the common lowland species $P$. latifolia, a conclusion similar to that of Macias (1988). In any case, $P$. coriacea also has priority over $P$. panamensis.

In contrast to the description in the protologue, numerous Posoqueria specimens from southern Central America and northwestern South America that have been included in $P$. panamensis by Steyermark (1967) and other recent authors mostly have flowers with actinomorphic androecia and leaves that are not shiny when dry. These misidentified plants are here separated into several newly described species: $P$. chocoana, $P$. correana, $P$. costaricensis, $P$. grandifructa, $P$. longifilamentosa, and $P$. robusta. Other Posoqueria specimens from northern South America that have been included in P. panamensis (e.g., Taylor et al., 2004; Steyermark, 1974), and that do have flowers with asymmetric androecia, have not been studied here; at least some 
of these apparently are correctly called $P$. trinitatis (Macias, 1988).

In the southern part of Central America, Posoqueria latifolia is most similar to $P$. coriacea, and these two species are sympatric and sometimes difficult to distinguish at middle elevations. Posoqueria coriacea can be recognized by its stipules $3-9 \mathrm{~mm}$ long and its fruits $7-8 \mathrm{~cm}$ diam. with the walls $4-6 \mathrm{~mm}$ thick and the seeds $10-15 \mathrm{~mm}$ long, versus in P. latifolia the stipules 5-22 $\mathrm{mm}$ long and the smaller, thinnerwalled fruits $3.5-5 \mathrm{~cm}$ diam. with the walls $1-3 \mathrm{~mm}$ thick and the seeds $4-8 \mathrm{~mm}$ long. Additionally, the calyx lobes help distinguish the two: in P. latifolia they are poorly developed, with the calyx limb nearly truncate or the lobes are short, broadly triangular, and have the margins minutely ciliolate and not overlapping at the sinus; in contrast, in P. coriacea the calyx lobes are clearly developed, broadly rounded, and have the margins ciliate and overlapping at the sinus.

\section{TaXonomy and Methods}

The new species described below are documented by specimens made by projects focused on floristic study of tropical forest regions that are not well known to science, with most of the collections made within the last 15 years. Additional collection data for the specimens cited here and high-resolution digital images of the type specimens are available on the Internet at $<$ http://www.tropicos.org $>$. Because of the size of the flowers and fruits of Posoqueria, to facilitate comparisons among species the inflorescence and infructescence sizes in the descriptions here are measured without the corollas and fruits. Thus the measurements given for the inflorescences include the peduncle, axes, pedicels, ovaries, and calyx limbs, but not the corollas; the measurements given for the infructescences include the peduncle, axes, and pedicels.

Conservation status assessment methodology. The study presented here is taxonomic and floristic: the objective is enumeration of the species that belong to various Rubiaceae genera, and the species that occur in the area of tropical Central and South America. The methods employed correspond only to this objective, so this study is based on survey of specimens collected over a number of years using varied survey methods aimed at various objectives. The specimens used to delineate the range and commonness of these new species were located through a nonexhaustive survey of several herbaria, and no field studies have been done targeting the occurrence of these species where they are known or expected to grow. Thus the floristic information presented here is a simplified presence report based on incomplete survey of the available data, which are uneven and incomplete for this region (Schulman et al., 2007). Knowledge of the true geographic range and the population size and dynamics of a species is essential to understanding the threats to its existence, and thus to understanding its actual conservation status; documentation of the existence of a species based on one or several museum collections does not provide adequate data to evaluate these factors. Conservation assessments are provided here for these newly described species using IUCN categories and criteria (IUCN, 2001) based on the totality of our current knowledge. The basis for these assessments in the form of a map and the calculated assessment parameters are available under the corresponding species names at $<$ http://www.tropicos.org $>$ (assessment parameters for each map can be seen by clicking on the thumbnail map). The assessment parameters were calculated using the IUCN Rating tool (Moat, 2007) in ArcView GIS 3.2 (ESRI, 1999), with the grid cell size used for calculating Area of Occupancy (AOO) varied between 1 and $3.16 \mathrm{~km}$ depending on characteristics of the species and data (IUCN Standards and Petitions Working Group, 2008). These assessments are not being submitted to IUCN for publication on the Red List $(<\mathrm{http}: / /$ www.iucnredlist.org $>$ ), and the basis for these assessments should be carefully evaluated by the reader.

\section{New Species of Posoqueria}

1. Posoqueria chocoana C. M. Taylor, sp. nov. TYPE: Panama. Panamá: El Llano-Cartí rd. ca. $18 \mathrm{~km}$ from Pan Am. Hwy., $9^{\circ} 20^{\prime} \mathrm{N}, 79^{\circ} 00^{\prime} \mathrm{W}$, $400 \mathrm{~m}, 28$ Dec. 1982, B. A. Stein 1046 (holotype, PMA; isotype, MO-3108923). Figure IC, D.

Haec species a congeneris foliis subtenacibus, corolla magnitudine media lobis rectis usque in alabastro subdeflexis, antheris partim breviterve exsertis filamenta aequantibus atque fructu subgloboso usque ovoideo laevi distinguitur.

Small to medium-sized trees, flowering at $6 \mathrm{~m}$ tall, to $20 \mathrm{~m}$ tall; stems glabrous, apparently somewhat succulent. Leaves with blade elliptic, broadly elliptic, or ovate, 10-33.5 ×5-21 cm, apex acute to acuminate with tips to $2 \mathrm{~cm}$ or rarely obtuse, base obtuse to rounded or truncate, glabrous, drying papery to subcoriaceous, adaxially matte or slightly shiny, and often paler abaxially; secondary veins 4 to 7 pairs, plane to prominulous adaxially, 


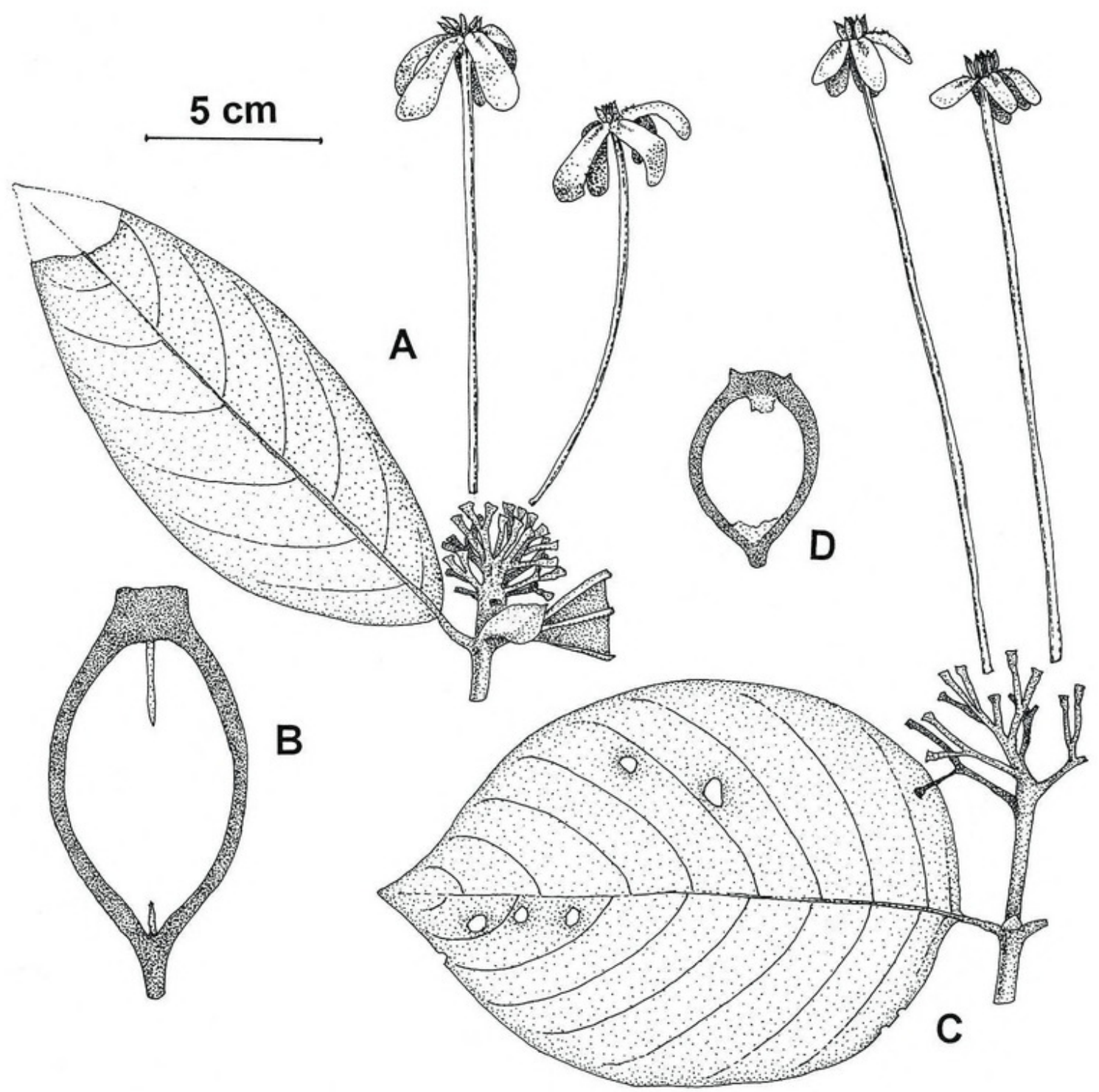

Figure 1. A, B. Posoqueria correana C. M. Taylor. -A. Portion of flowering stem, with flowers partially dissected; based on the type Merello \& González 3198 (MO). - B. Longitudinal section of fruit, perpendicular to septum, placentas and seed mass removed; based on the paratype Herrera 1224 (MO). C, D. P. chocoana C. M. Taylor. - C. Portion of flowering stem, with flowers partially dissected; based on the paratype Clark \& Troya 502 (MO). - D. Longitudinal section of fruit, parallel to septum, placentas and seed mass removed; based on the paratype Oliver et al. 3661 (MO).

prominulous abaxially, the costa plane to prominulous adaxially, prominent abaxially, the remaining venation plane and not visible on both sides; margins flat or usually thinly revolute; petioles 1-3 $\mathrm{cm}$, stout, glabrous; stipules interpetiolar, elliptic to lanceolate or ligulate, $10-30 \mathrm{~mm}$, obtuse to rounded, glabrous, sometimes longitudinally veined, deciduous. Inflorescence terminal, cymose, 4-8 $\times 4-7 \mathrm{~cm}$ (not including corollas or fruits), puberulous to glabrescent; bracts ligulate or ovate, 1-2 mm, obtuse; pedicels $3-10 \mathrm{~mm}$. Flowers with ovary portion obconic, ca. $2 \mathrm{~mm}$, glabrous; calyx limb 1.5-2 mm, lobed for ca. $1 / 4$, glabrous, lobes broadly triangular, obtuse to rounded, entire or ciliolate, marginally often hyaline; corolla in bud with lobes straight or slightly deflexed, at anthesis white, salverform, externally glabrous, tube 135-175 mm, 2-3 mm diam., hirtellous in throat and onto bases of lobes, lobes 5 , narrowly elliptic, obtuse to rounded, the shortest lobe $16-17 \mathrm{~mm}$, the longest lobe 19-20 $\mathrm{mm}$; stamens with filaments $2-2.2 \mathrm{~mm}$, equal or slightly unequal, inserted $1-1.5 \mathrm{~mm}$ below top of corolla tube, anthers narrowly oblong to fusiform, ca. $6 \mathrm{~mm}$, abaxially shortly puberulous, at apex and base with narrowly triangular sterile appendage ca. 1 $\mathrm{mm}$; stigmas not seen. Fruit subglobose to ovoid, 5$7 \times 5-7 \mathrm{~cm}$, becoming white then brown, smooth perhaps becoming slightly roughened; mesocarp woody or leathery, $3-4 \mathrm{~mm}$ thick; seeds ca. $1 \mathrm{~cm}$, broadly angled. 
Habitat, distribution, and phenology. Posoqueria chocoana is known from wet forests at $0-700 \mathrm{~m}$ from central Panama to central-western Ecuador and was collected with flowers in March and June through September and with fruits in January, August, September, November, and December.

\section{IUCN Red List category. Posoqueria chocoana} fails to meet the geographic range criterion for any threatened category, and it is documented from four legally protected areas in two countries. This species is here evaluated as Least Concern (LC), although if habitats in its region of distribution including in these protected areas begin to decline then this species could be considered Near Threatened or even Vulnerable.

Discussion. This new species is distinguished by its combination of often rather leathery leaves with stout petioles and the higher-order venation not visible, its medium-sized corollas (for Posoqueria) with the lobes slightly unequal in length on an individual flower and straight or slightly deflexed in bud, its partially included to shortly exserted anthers on filaments of generally equal lengths, and its subglobose to ovoid, generally smooth fruits. This new species is known from a range that generally corresponds to the Chocó biogeographic region of northwestern South America and eastern Panama (Gentry, 1982), and the specific epithet refers to this distribution.

This new species has previously been identified as Posoqueria panamensis; see the discussion in the introduction of the taxonomic problems with the circumscription of that species. Posoqueria chocoana is similar to $P$. grandifructa, described later in this article, but $P$. grandifructa can be separated by its usually narrower leaves (4-14 cm wide), its usually shorter stipules (5-13 mm long), its flowers with the ovary portion larger (ca. $4 \mathrm{~mm}$ long), its corollas with stouter tubes (2.5-4 mm diam.), and its larger ellipsoid fruits (to $13 \times 9 \mathrm{~cm}$ with the mesocarp 5$8 \mathrm{~mm}$ thick). Also similar to this new species is $P$. correana, described later in this article, which can be separated by its leaves that are densely velutinous abaxially, its smaller corollas with the tube $11-13 \mathrm{~cm}$ long, and its larger ellipsoid fruits (to $12 \times 5.5 \mathrm{~cm}$ with the mesocarp ca. $5 \mathrm{~mm}$ thick).

Paratypes. CENTRAL AMERICA. PANAMA. Colón: Parque Nac. Portobelo, ribera del Río Guanche, $C$. Galdames \& C. Guerra 1903 (MO, SCZ), C. Galdames \& J. Aranda 4107 (MO, SCZ); along Río Guanche, E of Colón, H. Kennedy \& R. Foster 2196 (MO), G. McPherson 8504 (MO), E. Montenegro \& D. Taylor 1912 (MO), K. J. Sytsma 1648 (MO). Darién: Camp Summit, adjacent [to] DariénSan Blas border along Sea Level Canal Rte. 17, R. L. Oliver,
W. H. Blackwell, Jr. \& J. W. Nowicke 3661 (MO). Panamá: El Llano-Cartí rd., K. J. Sytsma 1049 (MO), 1 mi. past sawmill, T. Antonio 2528 (MO); ca. 17 km from Pan Am. Hwy., S. Knapp 1356 (MO), near border San Blas, G. McPherson 9775 (MO), lado Pacífico de la Cordillera de San Blas, cabecera del río Piria (Piriati), H. Herrera, J. Mojica \& J. Morris 1156 (MO). San Blas [Kuna Yala]: río Playón Chico, hacia el sendero que cruza la Cordillera de San Blas, H. Herrera 1771 (MO, PTBG); Cerro Brewster, headwaters of río Cangandí, G. de Nevers, H. Herrera, B. Hammel \& S. Charnley 5518 (MO). Veraguas: NW of Santa Fe, $11 \mathrm{~km}$ from Escuela Agrícola de Piedra, in valley of Río Dos Bocas, Atlantic slope, S. Mori \& J. Kallunki 3894 (MO).

SOUTH AMERICA. COLOMBIA. Chocó: Parque Nac. de Utría, en la falda de la serranía que bordea el río San Pichí, F. García C. \& E. D. Agualimpia 476 (CHOCO, MO). ECUADOR. Carchi: cantón Tulcán, Reserva Etnica AwáCanynbí, Chical, C. Quelal, C. Aulestia \& F. Nastacuáz 235 (MO, QCNE). Esmeraldas: cantón Quinindé, Bilsa Biol. Station, Mache Mtns., $35 \mathrm{~km}$ W of Quinindé, $5 \mathrm{~km}$ W Santa Isabel, J. L. Clark 176 (MO, QCNE), J. L. Clark \& Y. Troya 502 (MO, QCNE), D. Neill \& QCNE Botany Interns 12226 (MO, QCNE), W. Palacios, J. [L.] Clark \& N. Jaramillo 13558 (MO, QCNE). Los Ríos: cantón Quevedo, Cerro Centinela, Montañas de Ila, $10 \mathrm{~km}$ al E Patricia Pilar, $W$. Palacios \& E. Freire 7432 (MO, QCNE). Manabí: cantón Pedernales, Bosque Protector Cerro Pata de Pájaro, 15 km SE Pedernales, D. Neill \& QCNE Botany Interns 11338 (MO, QCNE); ca. $10 \mathrm{~km}$ E Pedernales, N. Pitman 1321 (MO), H. Vargas 1283 (MO, QCNE).

\section{Posoqueria correana C. M. Taylor, sp. nov. TYPE:} Panama. Colón: Teck Cominco Mining Concession, Camp Colina, along Quebrada Colina, $8^{\circ} 50^{\prime} \mathrm{N}, 80^{\circ} 40^{\prime} \mathrm{W}, 152 \mathrm{~m}, 3$ Mar. 2008, M. Merello \& J. I. González 3198 (holotype, PMA; isotype, MO-6120458). Figure 1A, B.

Haec species a congeneris foliis abaxialiter dense velutinis, corolla magnitudine media lobis rectis usque in alabastro subdeflexis, antheris partim breviterve exsertis filamenta aequantibus atque fructu grandi ellipsoideo distinguitur.

Small trees, flowering at $3 \mathrm{~m}$ tall, to $10 \mathrm{~m}$ tall; stems glabrous. Leaves with blade ovate, elliptic, or narrowly elliptic, $14.5-36 \times 7.5-24 \mathrm{~cm}$, apex acute to usually acuminate with slender tips to $1.5 \mathrm{~cm}$, base obtuse to rounded or shortly truncate, adaxially glabrous, abaxially densely velutinous, drying chartaceous to subcoriaceous and rather shiny adaxially; secondary veins 4 to 7 pairs, plane to sulcate adaxially, prominent abaxially, the costa prominent to prominulous adaxially, prominent abaxially, the remaining veins plane and not visible on both surfaces; margins thinly to markedly revolute; petioles $0.8-2.2 \mathrm{~cm}$, puberulous to glabrous; stipules interpetiolar, ligulate to elliptic or broadly elliptic, $12-27$ $\mathrm{mm}$, glabrous, obtuse to rounded, on vegetative nodes deciduous. Inflorescence terminal, subfasciculate to shortly cymose, $2-4 \times 2-5 \mathrm{~cm}$ (not including corollas 
or fruits), glabrous, with subtending stipules persistent until anthesis then quickly deciduous; bracts few, triangular or ligulate, 1-2 mm; pedicels 2-18 $\mathrm{mm}$. Flowers with ovary portion ellipsoid-cylindrical, 3-4 mm, glabrous; calyx limb 2-2.5 mm, glabrous, 5lobed shallowly or for up to $1 / 4$, lobes broadly rounded to triangular, obtuse, entire to ciliolate; corolla in bud with lobes straight or slightly deflexed, at anthesis white, salverform, externally glabrous, tube 110-130 mm, 2-2.5 mm diam., hirtellous in throat and onto midrib of lobes, lobes 5 , ligulate or oblanceolate, adaxially glabrous or densely puberulous, obtuse to rounded, entire, the shortest lobe 19$23 \mathrm{~mm}$, the longest lobe $24-30 \mathrm{~mm}$; stamens with filaments $2.5-3 \mathrm{~mm}$, equal or a little unequal, inserted ca. $2 \mathrm{~mm}$ below top of corolla tube, anthers narrowly ellipsoid to fusiform, $6-7 \mathrm{~mm}$, partially to shortly exserted, abaxially granular-puberulous, at apex and base with narrowly triangular sterile appendage $0.8-1 \mathrm{~mm}$; stigmas linear, ca. $2 \mathrm{~mm}$. Fruit ellipsoid, to $12 \times 5.5 \mathrm{~cm}$, mature color unknown, smooth or becoming roughened-lenticellate; mesocarp leathery or woody, ca. $5 \mathrm{~mm}$ thick; seeds $1-1.3 \mathrm{~cm}$, broadly angled.

Habitat, distribution, and phenology. Posoqueria correana is known from wet forests at $50-880 \mathrm{~m}$ in central Panama, and has been collected with flowers in March and September and with fruits (perhaps immature) in September and October.

IUCN Red List category. Posoqueria correana meets the geographic range criterion for an evaluation of Endangered based on its limited known Extent of Occurrence (EOO) and AOO. However, it is found in three different legally protected areas, presumably not all under immediate threat. Whether its habitat or populations are in continuing decline is unconfirmed, but this is likely, now or in the near future. This species is here evaluated as Vulnerable due to its few known locations that may have declining habitat (VU D2).

Discussion. This new species can be recognized by the combination of its leaves that are densely velutinous abaxially, rather shiny adaxially when dry with the higher-order venation not visible, and usually with a slender sharp tip; its usually compact inflorescence subtended by well-developed, rounded stipules that persist through anthesis and with welldeveloped pedicels that are often longer than the secondary and tertiary axes; its medium-sized (for Posoqueria) corollas with the lobes straight to slightly deflexed in bud; its anthers partially included to very shortly exserted on filaments of generally equal length; and its large, thick-walled fruit. This new species is only known from Panama, and is named in honor of Panamanian botanist Mireya D. Correa, who has significantly advanced knowledge of the Panamanian flora and development of botanical infrastructure (herbaria, databases, and maps) and collaboration throughout Central America as well as training many younger botanists.

This new species is similar in general aspect to Posoqueria coriacea, and has been confused with that species; however, $P$. coriacea can be separated by its leaves that are glabrous or puberulous abaxially (in Panama), its corollas with the lobes markedly unequal and deflexed in bud, its anthers well exserted on markedly unequal filaments, its subglobose smooth fruits, and its habitat in premontane and montane vegetation. Also similar to this new species are $P$. grandiflora, which can be separated by its larger corollas with the tube $260-360 \mathrm{~mm}$ long and the lobes markedly deflexed in bud, and its anthers well exserted on markedly unequal filaments; and $P$. grandifructa, which can be separated by its leaves that are glabrous abaxially and usually more papery, its acute stipules with those subtending the inflorescence deciduous at the beginning of anthesis, and its often larger corollas with the tube 125-155 mm long.

Paratypes. PANAMA. Coclé: $7 \mathrm{~km} \mathrm{~N}$ of El Copé, near Rivera Sawmill, J. P. Folsom 5238 (MO, PTBG); división cont. arriba del Barrigón y el aserradero viejo, camino de caballo a Coclesito, M. Peña, R. Foster, R. Pérez, S. Aguilar, A. Hernández, Z. Batista \& R. Mihalik 394 (F, MO, PMA). San Blas [Kuna Yala]: vecindad de Yannuadi, frente a la Isla de Narganá, a $5 \mathrm{~km}$ de la costa, H. Herrera, B. Obaldia \& D. Escobar 1224 (MO, PMA).

3. Posoqueria costaricensis C. M. Taylor, sp. nov. TYPE: Costa Rica. Alajuela: Reserva Biol. Monteverde, Río Peñas Blancas, $10^{\circ} 18^{\prime} \mathrm{N}$, $84^{\circ} 45^{\prime}$ W, 900 m, 15 May 1987, W. Haber \& E. Bello 7037 (holotype, CR; isotypes, DUKE333971, INB-566355, MO-3715245). Figure 2C, D.

Haec species a congeneris corolla sat brevi lobis plerumque in alabastro rectis atque antheris partim inclusis usque breviter exsertis erectis filamentis brevibus insidentibus distinguitur.

Small trees, flowering at $2.5 \mathrm{~m}$ tall, to $10 \mathrm{~m}$ tall; stems glabrous. Leaves with blades elliptic, lanceolate, or narrowly elliptic-lanceolate, 6.5-17 × 2.2$6.2 \mathrm{~cm}$, apex acute to acuminate with tip to $0.8 \mathrm{~cm}$, base acute to obtuse, glabrous, drying papery to coriaceous and adaxially matte to shiny; secondary veins 4 to 6 pairs, prominulous on both surfaces, the costa prominulous adaxially, prominent abaxially, 


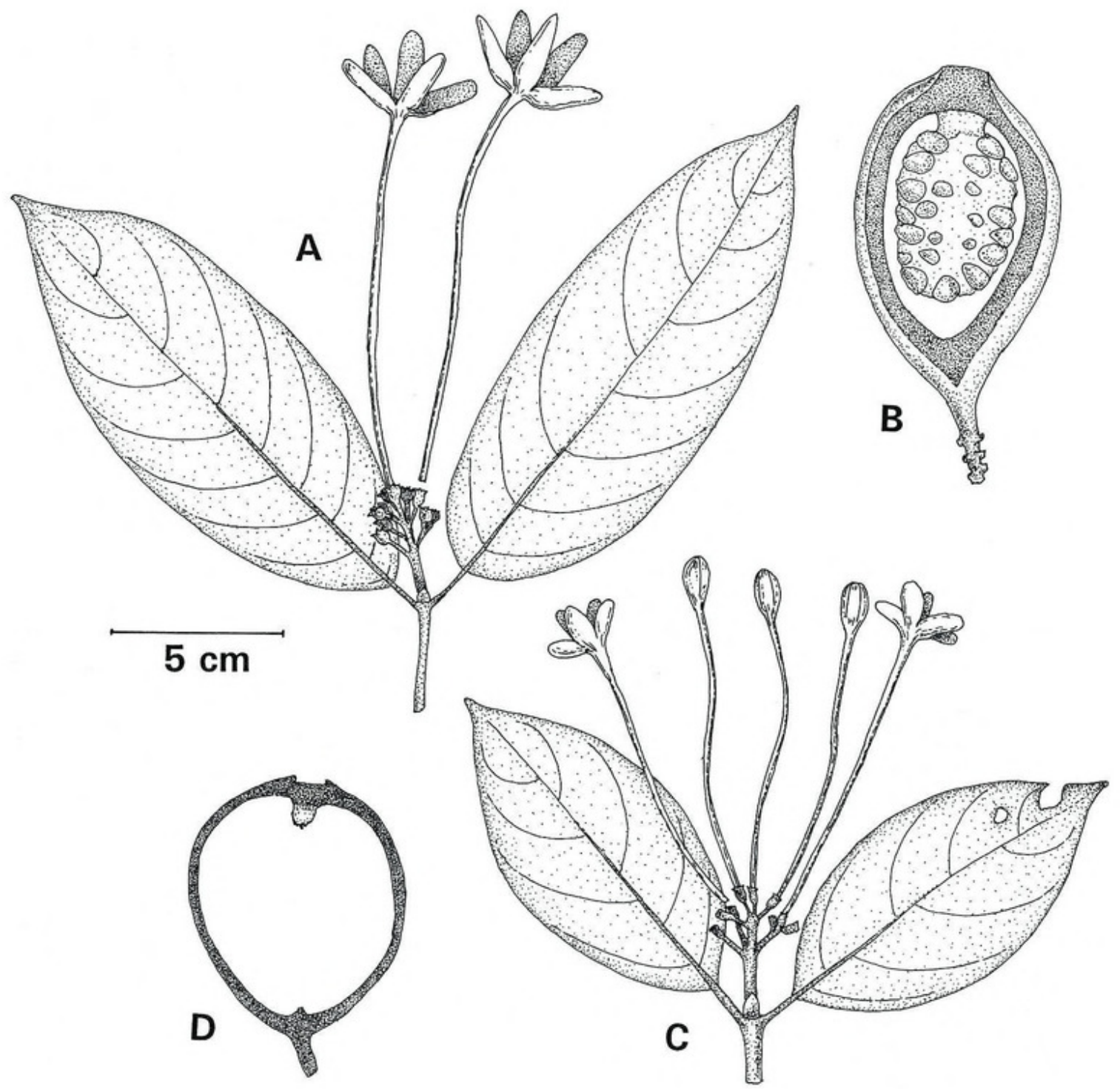

Figure 2. A, B. Posoqueria grandifructa Hammel \& C. M. Taylor. -A. Portion of flowering stem, right-hand flower partially dissected; based on the paratype Stevens 23665 (MO). - B. Longitudinal section of fruit, parallel to septum; based on the paratype McDowell 726 (DUKE). C, D. P. costaricensis C. M. Taylor. - C. Portion of flowering stem; based on the type Haber \& Bello 7037 (MO). - D. Longitudinal section of fruit, perpendicular to septum, placentas and seed mass removed; based on the paratype McPherson 12538 (MO).

the remaining veins plane and not or sparsely visible adaxially, plane or sparsely raised abaxially; margins plane to thinly revolute; petioles $5-15 \mathrm{~mm}$, glabrous; stipules interpetiolar, triangular, ligulate, or lanceolate, 5-9 mm, acute, glabrous, often with wellmarked longitudinal striations or veins, deciduous below terminal 1 to 2 nodes. Inflorescence terminal, cymose, $2.5-6 \times 1.5-5 \mathrm{~cm}$ (not including corollas or fruits), pilosulose to glabrous; bracts ligulate to ovate, $0.3-2 \mathrm{~mm}$; pedicels $5-15 \mathrm{~mm}$. Flowers with ovary portion ellipsoid-obconic, $2-3.5 \mathrm{~mm}$, glabrous; calyx limb 1-1.5 mm, glabrous, almost truncate to 5lobed for up to $1 / 3$, lobes broadly rounded to triangular, with margins minutely papillose-ciliolate and often hyaline; corolla in bud with the lobes held more or less straight with respect to the tube, at anthesis white, salverform, externally glabrous, tube 70-90 mm, 1-2 mm diam., sparsely to densely hirtellous in throat and sometimes onto lobes, lobes 5 , elliptic to ligulate, obtuse to rounded, entire, the shortest lobe $11-13 \mathrm{~mm}$, the longest lobe $12-15 \mathrm{~mm}$; stamens with filaments ca. $2 \mathrm{~mm}$, equal or a little unequal, inserted ca. $1 \mathrm{~mm}$ below top of corolla tube, anthers narrowly ellipsoid, ca. $4 \mathrm{~mm}$, partially included to shortly exserted, abaxially puberulous, at base with triangular acute sterile portion ca. 0.8 $\mathrm{mm}$, at apex with triangular acute sterile portion ca. $1 \mathrm{~mm}$; stigmas linear, $2-3 \mathrm{~mm}$. Fruit subglobose, $6.5-8 \times 6.5-8 \mathrm{~cm}$, externally slightly to markedly roughened, brown and slightly crustose; mesocarp woody, 4-5 mm thick; seeds angled, $1-1.5 \mathrm{~cm}$, smooth. 
Habitat, distribution, and phenology. Posoqueria costaricensis is known from wet and premontane forests at 800-1760 m in Costa Rica and Panama and has been collected with flowers in January, February, and May and with apparently mature fruits in April, August, and December.

IUCN Red List category. Posoqueria costaricensis meets the geographic range criterion for an evaluation of Vulnerable due to its limited EOO and not more than 10 locations (i.e., different threat regimes), and for Endangered due to its limited AOO. It is known from three legally protected areas in two countries. There is no clear documentation of ongoing continuing decline in the habitat of these particular protected areas; however, this species seems to occupy a relatively narrow elevational zone in wet forest that is generally in significant decline throughout this region, therefore this species is here assessed as Vulnerable due to habitat decline (VU Blab[iii]+ 2ab[iii]).

Discussion. This new species can be recognized by the combination of its calyx limb that is nearly truncate or shallowly lobed with the lobes broadly rounded and marginally papillose-ciliolate, its medium-sized (for Posoqueria) corollas with the lobes held more or less straight in bud, its anthers that are partially included or only barely exserted on filaments of generally similar length, and its subglobose fruits with rather thick woody walls that become brown and slightly crustose on the outside. This new species has previously been included in $P$. panamensis; see the discussion in the introduction of the taxonomic problems with the circumscription of that species.

Posoqueria costaricensis apparently may be locally sympatric with $P$. coriacea, and without flowers or fully mature fruits these two species can be difficult to distinguish. With flowers, P. coriacea can be recognized by its distinctive calyx lobes that are marginally ciliate and broadly rounded with the basal margins often overlapping in the sinus and its asymmetric androecium with the anthers well exserted on filaments of unequal length. The fruits of $P$. coriacea apparently remain green and smooth at maturity, while those of $P$. costaricensis become brown and slightly crustose. Although many of the specimens of $P$. costaricensis have the dried leaves matte on the adaxial surface, others (e.g., Alfaro 493, Quesada 1719, Rodríguez et al. 10107) have somewhat shiny leaves that are thus similar to those of $P$. coriacea. See also the discussion of $P$. grandifructa, described later in this article, which is also found in Costa Rica; P. grandifructa can be separated by its usually more papery leaves and its corollas similar to those of $P$. costaricensis but with longer tubes (105-155 mm), and is found at mostly lower elevations on the Caribbean slopes of Costa Rica and Nicaragua.

Paratypes. COSTA RICA. Alajuela: Bosque Eterno de los Niños, Río Peñas Blancas, Quebrada Gata, Los Pérez, E. Bello, W. Haber, W. Zuchowski \& J. Sibaja 2189 (INB); Reserva Biol. Monteverde, Río Peñas Blancas, Finca García, W. Haber \& E. Cruz 7716 (CR, MO). Guanacaste: Río Negro ford on $\mathrm{S}$ side of Lake Arenal, $10 \mathrm{~km} \mathrm{NNE}$ of Santa Elena, W. A. Haber ex E. Bello C., L. Lierheimer \& B. Hammel 4880 (DUKE, PTBG). Puntarenas: Sabanas Esperanza, Biolley, Javier Quesada 1719 (INB); Potrero Grande, Tres Colinas, bajando hacia Helechales, A. Rodríguez, D. Solano \& D. Santamaría 10107 (INB); Las Cruces Botanical Garden, near San Vito, T. B. Croat 44385 (MO), R. L. Wilbur, F. Almeda \& T. Daniel 22824 (DUKE). San José: cantón de Pérez Zeledón, Cordillera de Talamanca, Las Nubes, Estación Santa Elena, E. Alfaro 493 (INB, MO). PANAMA. Bocas del Toro: Fortuna Dam area, Oleoducto rd. near Cont. Divide, H. W. Churchill, G. de Nevers \& H. Stockwell 4695 (MO, PTBG), G. McPherson \& J. Aranda 10164 (MO); along rd. toward Chiriquí Grande, along trail leaving rd. at $500 \mathrm{~m}$, G. McPherson 12538 (MO).

4. Posoqueria grandifrueta Hammel \& C. M. Taylor, sp. nov. TYPE: Costa Rica. Heredia: cantón Sarapiquí, Finca La Selva, OTS biological station on the Río Puerto Viejo just $\mathrm{E}$ of jet. with Río Sarapiquí, ca. 100 m, 22 Feb. 1981, J. Folsom 9100 (holotype, MO-3417484; isotype, DUKE-28904). Figure 2A, B.

Haec species a Posoqueria latifolia (Rudge) Roem. \& Schult. corollae lobis in alabastro plerumque rectis, antheris partim inclusis vel perbreviter exsertis filamenta aequantibus atque fructu sat grandi ellipsoideo subfusiformive extus asperato lepidotove distinguitur.

Shrubs or small trees flowering at $2.5 \mathrm{~m}$ tall, to $8 \mathrm{~m}$ tall; stems puberulous to glabrous, often apparently rather succulent and becoming longitudinally finely wrinkled when dried. Leaves with blade elliptic, narrowly elliptic, or lanceolate-elliptic, 11-26 × 4$14 \mathrm{~cm}$, apex acute to acuminate with tips to $0.8 \mathrm{~cm}$, base obtuse to rounded or truncate, glabrous or often abaxially puberulous at least along principal veins, drying stiffly papyraceous to stiffly chartaceous and adaxially matte; secondary veins 4 to 7 pairs, visible and plane or raised adaxially, prominulous abaxially, the costa thinly prominulous adaxially, prominent abaxially, the remaining veins not visible or sometimes visible and plane to raised adaxially, not visible or sometimes sparsely visible abaxially; margins flat or thinly revolute; petiole $5-15 \mathrm{~mm}$, glabrous; stipules interpetiolar, ligulate to narrowly triangular, 5-13 $\mathrm{mm}$, acute, glabrous, often longitudinally ridged or 
veined, caducous. Inflorescences terminal, cymose, $2.5-5 \times 2-4 \mathrm{~cm}$ (not including corollas or fruits), puberulous to glabrous; bracts few, triangular, 0.5-2 $\mathrm{mm}$, acute; pedicels $3-10 \mathrm{~mm}$. Flowers with ovary portion ellipsoid-cylindrical, ca. $4 \mathrm{~mm}$, glabrous; calyx limb 1-2 mm, glabrous, 5-lobed for ca. 1/2, lobes broadly triangular, acute to rounded, with margins entire or ciliolate, often hyaline; corolla in bud with lobes generally straight, at anthesis white, salverform, externally glabrous, tube (105-)125-155 $\mathrm{mm}, 2.5-4 \mathrm{~mm}$ diam., hirtellous to pilose in throat and sometimes onto lobes, lobes 5 , narrowly ligulate, obtuse to rounded, entire, the shortest lobe 17-20 $\mathrm{mm}$, the longest lobe $30-37 \mathrm{~mm}$; stamens with filaments ca. $3 \mathrm{~mm}$, equal or slightly unequal, inserted $2-3 \mathrm{~mm}$ below top of corolla tube, anthers lanceoloid, ca. $6 \mathrm{~mm}$, partially included to just exserted, abaxially puberulous, at base with triangular acute sterile portion ca. $1 \mathrm{~mm}$, at apex with triangular acute sterile portion ca. $1 \mathrm{~mm}$; stigmas not seen. Fruits ellipsoid to somewhat fusiform, to $13 \times 9$ $\mathrm{cm}$, dull brown, leathery, outside becoming roughened or scaly; mesocarp leathery to woody, $5-8 \mathrm{~mm}$ thick; seeds angled, $1-1.5 \mathrm{~cm}$.

Habitat, distribution, and phenology. Posoqueria grandifructa is known from wet and premontane forests at $10-1000 \mathrm{~m}$ on the Caribbean slopes of Nicaragua and Costa Rica and rarely (A. F. Skutch 2805) on the Pacific slopes of Costa Rica; it has been collected with flowers in January, February, April, August, and September, and with fruits January, March, and June through December.

\section{IUCN Red List category. Posoqueria grandifructa} does not meet the geographic range criterion for any threatened category due to its relatively large EOO, and with more than 10 locations, the somewhat limited AOO is not a risk factor. This species is known from nine legally protected areas and one private protected area in two countries, and apparently is common locally and grows in secondary woody vegetation. There is ongoing habitat decline in its habitat throughout this region; however, due to its failure to meet the thresholds for any threatened category, together with the frequency of its recent collection, this species is here considered Least Concern (LC).

Discussion. This new species can be recognized by the combination of its leaves that are matte on the adaxial surface at least when dry and are often puberulent on the abaxial surface along the costa and often also the secondary veins, its relatively large corollas with the lobes generally straight in bud, its anthers that are partially included to just exserted on generally equal filaments that are inserted below the top of the corolla tube, and its relatively large, ellipsoid, thickly leathery- to woody-walled fruits that become markedly roughened at maturity. The specific epithet refers to these distinctive large mature fruits. The immature fruits of Posoqueria grandifructa are generally subglobose and smooth, then during development the calyx limb scar enlarges in diameter, the apical portion begins to elongate, and the surface becomes roughened. This new species has previously been identified as $P$. panamensis; see the discussion in the introduction of the taxonomic problems with the circumscription of that species.

Posoqueria grandifructa is similar to the sympatric species $P$. latifolia, but $P$. latifolia can be recognized by its leaves that are usually shiny on the adaxial surface when dry, its corolla buds with the lobe portion deflexed at $30^{\circ}-45^{\circ}$ with respect to the tube, its anthers fully exserted on well-developed flexuous filaments of unequal length, and its smaller subglobose fruits $(3.5-5 \mathrm{~cm}$ diam.) with rather thin, stiffly chartaceous to thinly woody walls. Posoqueria grandifructa is even more similar to $P$. costaricensis, described previously in this article, with which it shares the symmetric, nonexplosive androecium and relatively large crustose fruits, and these two species are sometimes locally sympatric at the extremes of their elevational ranges. However, $P$. grandifructa can be recognized by its usually larger leaves that are often puberulent abaxially and its longer corolla tubes (105-155 mm), in contrast to the leaves glabrous abaxially and the corolla tubes shorter (70-90 mm long) in P. costaricensis.

Some plants of Posoqueria grandifructa from the Cordillera de Tilarán, at the uppermost elevation of the range reported here for this species (Herrera 509, Herrera \& Solís 444), differ from the plants of lower elevations and other regions in having leaves that are truncate at the base and corolla lobes that are elliptic with the margins rounded, but the flowers of all of these plants are similar.

Paratypes. COSTA RICA. Alajuela: Parque Nac. Arenal, Cerro Chato, A. Rodríguez, V. Ramírez \& G. Soto 6251 (INB); Reserva Forestal de Arenal, Monteverde, Río Aguas Gatas, Finca Ulate, E. Bello 1878 (CR, INB, MO); Reserva Biol. Monteverde, Río Peñas Blancas, Bosque Eterno de Los Niños, E. Bello 2049 (INB); Reserva Biol. Monteverde, San Ramón, Est. Alemán's, E. Bello, E. Cruz \& R. Cruz 4060 (INB), W. Haber \& E. Cruz 8004 (CR, MO); entrada de la Reserva Forestal de San Ramón, camino a la colonia Palmareña, margen derecha río San Lorenzito, finca de Don Bolívar Ruíz, G. Herrera Ch. 509 (CR, MO), G. Herrera Ch. \& A. Solís B. 444 (MO, PTBG). Heredia: Parque Nac. Braulio Carrillo, Fila Carrillo, L. G. [L. D.] Gómez, I. A. Chacón \& G. Herrera 21148 (CR, DUKE, MO); Quebrada González, V. Ramírez 458 (INB, MO); cantón de Sarapiquí, Finca La Selva, OTS biol. station at jct. of ríos 
Sarapiquí \& Puerto Viejo (former property of L. Holdridge), W. Burger \& G. Matta U. [G. Mata U.] 4255 (F, MO), J. Folsom 8888 (DUKE, MO), 9280 (DUKE), 9876 (DUKE), B. Hammel 8443 (DUKE), 10108 (DUKE), B. Hammel \& J. Trainer 13146 (DUKE), G. S. Hartshorn 900 (MO), B. Jacobs 2228 (DUKE), 2428 (DUKE), R. Kriebel, N. Zamora \& R. Aguilar 3520 (INB), T. McDowell 726 (DUKE, MO), $P$. A. Opler 41 (MO), D. [A.] Smith 47 (DUKE), R. L. Wilbur \& G. Moore 70201 (DUKE); Parque Nac. Braulio Carrillo, Est. Magsasay, A. Fernández 82 (INB), B. Hammel, A. Gentry \& H. Kennedy 17827 (CR, MO); entre Bijagual y Magsasay, $L$. D. Vargas, A. Rodríguez \& E. Ureña 41 (INB, MO); Llanura de San Carlos, Caño Negro del sur, B. Hammel, A. Rodríguez \& V. Ramírez 21199 (INB); Guápiles, V. Ramúrez 458 (INB, MO); Rara Avis, ca. $15 \mathrm{~km}$ al SO de Horquetas, O. Vargas 264 (CR, MO). Limón: Cerro Coronel, W. D. Stevens 23665 (MO), W. D. Stevens, G. Herrera \& O. M. Montiel 24762 (MO), 24827 (MO); cantón de Pococí, R.N.F.S. Barra del Colorado, Llanura de Tortuguero, Sandinas, F. Araya 597 (INB, MO); Parque Nac. Tortuguero, Est. Agua Fría, R. Robles 1235 (CR, MO), J. Solano 58 (INB, MO), 246 (INB, MO); cantón de Limón, Cerro Muchilla, Fila Matama, R. Robles \& A. Chacón 2663 (CR, MO); cantón de Talamanca, Sukut, ca. de juntas de ríos Urén y Sukut, G. Herrera 3216 (CR, MO); at Recope site near Bribri, near Panama border, C. M. Taylor \& C. Skotak 4451 (DUKE). San José: vic. of El General, A. F. Skutch 2805 (MO). NICARAGUA. Río San Juan: sobre río San Juan en caño el Sarnoso, 1 hora río abajo del pueso de MARENA, Bartola, R. Rueda, B. Hernández \& E. Palma 1982 (HULE, MO); mpio. del Castillo, Reserva Indio-Maíz, a lo largo del caño Chontaleño, R. Rueda, I. Coronado, $O$. Aráuz \& F. Flores 5886 (HULE, MO), 6018 (HULE, MO), 6151 (HULE, MO). Zelaya: ca. de Colonia Yolaina, M. Araquistain 3117 (MO), W. D. Stevens 6455 (MO); Monkey Point, P. P. Moreno \& J. C. Sandino 12267 (MO); al E del poblado de Nueva Atlanta, R. Rueda, B. Hernández \& I. Coronado 3280 (HULE, MO); río Punta Gorda, al S de San José, R. Rueda, B. Hernández \& I. Coronado 3658 (HULE, MO); Cerro El Escobín, $4 \mathrm{~km}$ de Colonia Serrano, J. C. Sandino 3388 (MO).

5. Posoqueria longifilamentosa C. M. Taylor, sp. nov. TYPE: Ecuador. Esmeraldas: cantón Muisne, San Salvador, orillas del río Sucio, 100-150 m, [without day] Mar. 1995, W. Palacios 13759 (holotype, QCNE; isotype, MO5194790). Figure 3C, D.

Haec species a congeneris foliorum venis secundariis numerosis, venatione tertiaria quaternariaque subtiliter reticulata adaxialiter tenuiter prominente, corolla sat grandi, filamentis longis, antheris grandibus atque seminibus sat parvis distinguitur.

Small trees, flowering at $3 \mathrm{~m}$ tall, to $6 \mathrm{~m}$ tall; stems glabrous, apparently rather succulent, frequently becoming longitudinally finely wrinkled when dried. Leaves with blade elliptic or elliptic-oblong, 26.5-43 $\times 11-20 \mathrm{~cm}$, apex shortly acuminate with tips to 0.8 $\mathrm{cm}$, base obtuse to rounded, glabrous, drying thinly papery to chartaceous, adaxially matte, and pale abaxially; secondary veins 7 to 10 pairs, plane, thinly prominulous, or sulcate adaxially, prominulous abaxially, the costa plane or thinly prominulous adaxially, prominulous abaxially, the remaining veins finely reticulated and thinly raised adaxially, plane and not visible or sometimes sparsely visible abaxially; margins flat to thinly revolute; petioles 1.2-2.5 cm, glabrous; stipules interpetiolar, hastate sometimes above a rectangular basal portion, 4-20 $\mathrm{mm}$, obtuse to acute, glabrous, sometimes longitudinally ridged or veined, deciduous. Inflorescence terminal, cymose, 4-7 $\times$ 4-7 cm (not including corollas or fruits), glabrous; bracts few, ligulate to elliptic, 1-4 mm, rounded, entire or ciliolate; pedicels $5-30 \mathrm{~mm}$. Flowers with ovary portion obconic, 4-5 mm, glabrous; calyx limb ca. $2 \mathrm{~mm}$, puberulous or glabrous, 5-lobed for 1/4-1/2, lobes rounded, with margins ciliolate; corolla in bud with lobes deflexed, at anthesis white, salverform, externally glabrous, tube $269-272 \mathrm{~mm}, 2-3.5 \mathrm{~mm}$ diam., hirtellous in throat and onto basal part of lobes, lobes 5 , ligulate to narrowly elliptic, adaxially puberulous, obtuse to rounded, entire, the shortest lobe 28-30 $\mathrm{mm}$, the longest lobe ca. $40 \mathrm{~mm}$; stamens with filaments unequal, the shortest ca. $10 \mathrm{~mm}$, the longest ca. $20 \mathrm{~mm}$, anthers narrowly lanceoloid, 10$11 \mathrm{~mm}$, exserted, abaxially densely puberulous, at apex and base with narrowly triangular sterile appendages ca. $2 \mathrm{~mm}$; stigmas not seen. Fruits subglobose, 4.5-5 $\times$ 4.5-5 cm, mature color unknown, smooth perhaps becoming roughened; mesocarp leathery to woody, 2-3 mm thick; seeds $0.5-0.8 \mathrm{~mm}$, broadly angled.

Habitat, distribution, and phenology. Posoqueria longifilamentosa is known from wet forest at $100-470$ $\mathrm{m}$ in northwestern coastal Ecuador; it has been collected with flowers in March and May, and with fruits (though perhaps these are immature) in March and April.

IUCN Red List category. Posoqueria longifilamentosa meets the geographic range criterion for Endangered based on its limited EOO and AOO, in addition to its no more than five locations (i.e., distinct threat regimes). It is known from one national legally protected area and one indigenous-managed reserve. Although no ongoing significant decline in these protected areas has been documented, the vegetation in this region is under threat from development. However, this area is not well explored botanically and this species could be more common than specimen representation suggests. This species is here considered Vulnerable due to its few known locations that may have declining habitat (VU D2). 


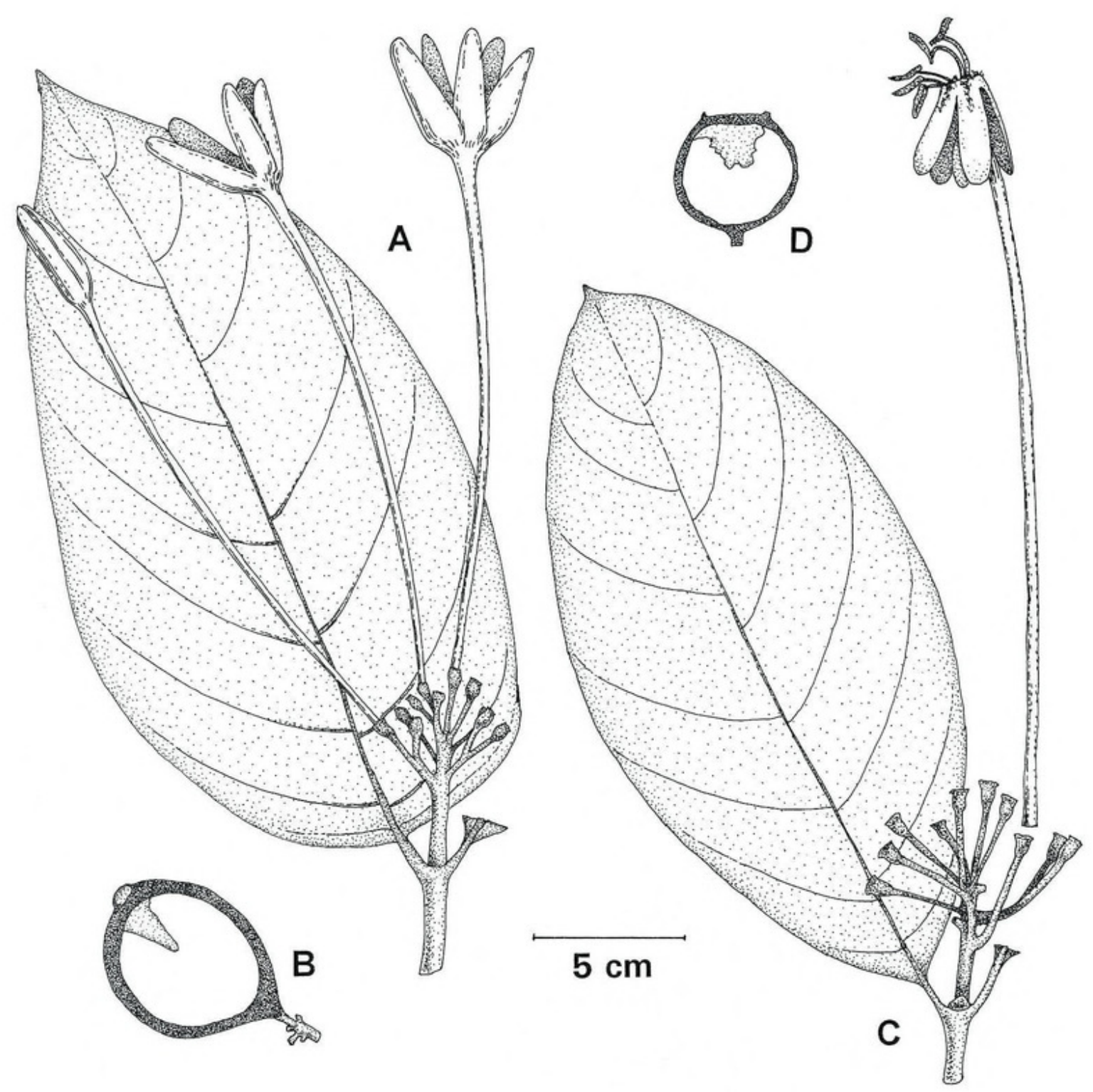

Figure 3. A, B. Posoqueria robusta Hammel \& C. M. Taylor. -A. Portion of flowering branch; based on the paratype Folsom 9172 (MO). - B. Longitudinal section of fruit, parallel to septum, placentas and seed mass removed; based on the paratype Ramírez et al. 216 (MO). C, D. P. longifilamentosa C. M. Taylor. - C. Portion of flowering branch, flower partially dissected; based on the paratype Clark et al. 4205 (MO). - D. Longitudinal section of fruit, parallel to septum, placentas and seed mass removed; based on the paratype Rubio \& Quelal 1390 (MO).

Discussion. This new species can be recognized by its leaves drying pale abaxially and with the higher-order venation finely reticulated and raised on the adaxial surface, its hastate stipules, its relatively long corollas, its asymmetric androecium with the filaments and anthers larger than in any other species of the genus, and its smooth subglobose fruits. The specific epithet refers to the relatively long filaments. This new species is only known from a rather small area in northwestern Ecuador, but probably should be expected also in adjacent western Colombia.

Paratypes. ECUADOR. Esmeraldas: Reserva MacheChindul, Cordillera Ene, ca. a la propiedad de Luis Cabrera, C. Bonifaz \& [X.] Cornejo 5043 (GUAY, MO);
Quiebra Perol, X. Cornejo \& C. Bonifaz 7773 (GUAY, MO); cantón Muisne, San Salvador, orillas del río Sucio, W. Palacios 13764 (MO, QCNE); cantón San Lorenzo, Reserva Indígena Awá, parroquia Ricaurte, comun. Balsareño, río Palabí, D. Rubio \& C. Quelal 1390 (MO, QCNE). Manabí: cantón Pedernales, Reserva Ecol. Mache-Chindul, comun. Ambacha, J. L. Clark, R. Dunn, T. Núñez \& C. Robles 4205 (MO, QCNE).

6. Posoqueria robusta Hammel \& C. M. Taylor, sp. nov. TYPE: Costa Rica. Heredia: cantón de Sarapiquí, Llanura de San Carlos, Lomas Sardinal, ca. $15 \mathrm{~km}$ línea recta $\mathrm{N}$ de Puerto Viejo de Sarapiquí, $10^{\circ} 34^{\prime} \mathrm{N}, 84^{\circ} 03^{\prime} \mathrm{W}, 250-$ 350 m, 12 Mar. 1994, B. Hammel \& M. Garita 
19531 (holotype, INB; isotypes, MO 04916434, MO 04916435). Figure 3 A, B.

Haec species a Posoqueria grandifructa Hammel \& C. M. Taylor foliis crassis, flore majore atque fructu subgloboso distinguitur.

Small to medium-sized trees flowering at $4.5 \mathrm{~m}$ tall, to $20 \mathrm{~m}$ tall; stems glabrous, perhaps somewhat succulent. Leaves with blade ovate, lanceolate-oblong, or lanceolate, $15-38.5 \times 4-18 \mathrm{~cm}$, apex acute to acuminate with tips to $1 \mathrm{~cm}$, base obtuse to truncate or rounded, glabrous, drying stiffly chartaceous to subcoriaceous and often brittle, matte to somewhat shiny adaxially; secondary veins 5 to 8 pairs, prominulous to plane or sulcate adaxially, prominulous abaxially, the costa prominulous adaxially, prominent abaxially, the remaining veins plane and not visible on both surfaces; margins thinly revolute; petiole 10-25 mm, glabrous, often rather stout; stipules interpetiolar or shortly fused around stem, ligulate to ovate, $5-20 \mathrm{~mm}$, acute to obtuse, glabrous, deciduous before leaves. Inflorescences terminal, cymose, $3-5 \times 2-4.5 \mathrm{~cm}$ (not including corollas or fruits), puberulous to glabrous; bracts ovate to ligulate, 1-3 mm, obtuse to acute, ciliolate; pedicels 2-17 mm. Flowers with ovary portion cylindricalellipsoid, 3.5-4 mm, glabrous; calyx limb 2-3 mm, glabrous, subtruncate or lobed, lobes up to $1 / 2$ of length of limb, broadly rounded, marginally nearly entire to irregularly ciliolate, sometimes hyaline; corolla in bud with lobes generally straight, at anthesis white, salverform, externally glabrous, tube $175-213 \mathrm{~mm}, 2-3 \mathrm{~mm}$ diam., granular-puberulous to sparsely hirtellous or pilose in throat and sometimes onto lobes, lobes 5 , narrowly ligulate or lanceolateoblong, obtuse to rounded, entire, the shortest lobe $30-40 \mathrm{~mm}$, the longest lobe $35-50 \mathrm{~mm}$; stamens with filaments $5-6 \mathrm{~mm}$, equal or slightly unequal, inserted 6-7 mm below top of corolla tube, anthers narrowly ellipsoid, ca. $7 \mathrm{~mm}$, partially included to just exserted, abaxially puberulous, at base and apex with triangular acute sterile portions ca. $1 \mathrm{~mm}$; stigmas not seen. Fruits subglobose, ca. $6 \times 6 \mathrm{~cm}$, brown, outside smooth or slightly roughened; mesocarp woody, 4-5 $\mathrm{mm}$ thick; seeds broadly angled, ca. $1 \mathrm{~cm}$.

Habitat, distribution, and phenology. Posoqueria robusta is known from wet forests at $10-400 \mathrm{~m}$ on the Caribbean slopes of Nicaragua and Costa Rica; it has been collected with flowers in January, March, May, September, and October, and with fruits in February, May, June, and September through November.

IUCN Red List category. Posoqueria robusta meets the geographic range criterion for Endangered based on its small EOO and its limited AOO. It is known from four governmentally protected areas as well as the La Selva Biological Station, a privately protected reserve. Although there is continuing decline in its habitat outside these protected areas, it is documented from what are here considered more than five but not more than 10 locations (i.e., areas subject to different kinds or degree of threat), and it is here considered Vulnerable due to habitat decline (VU Blab[iii] +2ab[iii]).

Discussion. This new species is distinguished by its leathery, usually relatively large leaves with the venation mostly immersed in the tissues of the blade and not visible, except the secondary veins are prominent on the abaxial surface and plane or sometimes sulcate on the adaxial surface; its relatively large corollas; its anthers that are partly included to shortly exserted on filaments of generally equal length; and its generally subglobose, smooth or slightly roughened fruits with woody, rather thin walls. The specific epithet refers to the often rather large, leathery leaves and the relatively large flowers. This new species has previously been identified as Posoqueria panamensis; see the discussion in the introduction of the taxonomic problems with the circumscription of that species.

This new species is similar to Posoqueria grandiflora, but the latter can be recognized by its ellipsoid larger fruits (8-11 cm long), its longer corollas with the tube $260-360 \mathrm{~mm}$ long and the lobes deflexed in bud, its anthers fully exserted on flexuous filaments of unequal length, and its leaves that are sometimes glabrous but usually shortly pilosulose or velutinous throughout abaxially. On the Caribbean slopes of Costa Rica where these two species are locally sympatric (e.g., the La Selva Biological Station), they are easily separated by the abaxially glabrous leaves of $P$. robusta versus the leaves clearly pubescent below in $P$. grandiflora. On the Pacific slopes of Costa Rica, P. grandiflora has leaves that are glabrous abaxially, but $P$. robusta has not been found in that region.

Paratypes. COSTA RICA. Alajuela: cantón de San Carlos, Parcela Pipasa, D. Solano \& N. Zamora 2774 (INB). Heredia: cantón de Sarapiquí, Parque Nac. Braulio Carrillo, Est. El Ceibo, R. Aguilar 16 (CR, M0), B. Boyle 3756 (INB), J. González 3182 (INB); Est. Magsaysay [Magsasay], C. Alvarado 77 (INB), A. Fernández 88 (INB, MO), L. D. Vargas, A. Rodríguez \& E. Ureña 38 (INB, MO); La Selva Protection Zone, Guácimo Ridge Trail, G. S. Hartshorn 2552 (MO); ca. 8 km SW of Puerto Viejo de Sarapiquí along [old] rd. to San José, W. Burger \& G. Matta U. [G. Mata U.] 4275 (DUKE, F, MO); Finca La Selva, OTS biol. station at jet. of Ríos Sarapiquí \& Puerto Viejo, J. Folsom 9172 (DUKE, MO), 9632 (DUKE, MO), M. Grayum 2528 (DUKE), B. Jacobs 3008 (DUKE), T. McDowell 726 
(DUKE), D. Smith 460 (DUKE); Chilamate de Sarapiquí, S base of Cerros Sardinal, Finca El Bejuco, M. H. Grayum \& B. Jacobs 5324 (MO), D. A. Smith \& G. Schatz 1214 (DUKE, MO); Bijagual, camino a Magsaysay [Magsasay], $Q$. Jiménez, B. Hammel, R. Rueda, E. Lépiz \& V. Ramírez 1445 (INB, MO), V. Ramírez, Q. Jiménez \& B. Hammel 216 (INB, MO); Lomas Sardinal, N de Puerto Viejo, B. Hammel 20670 (INB), B. Hammel, A. Rodríguez \& V. Ramírez 21198 (INB). Limón: cantón de Pococí, Llanura de Tortuguero, El Cedral, $26 \mathrm{~km} \mathrm{~N}$ of Cariari, K. Thomsen 1180 (C, MO); Cariari, Palmitas, El Triángulo, Las Brisas, Q. Jiménez, A. Estrada \& L. D. Vargas 2099 (INB, MO). NICARAGUA. Río San Juan: $1.5 \mathrm{~km} \mathrm{~W} \mathrm{(above)} \mathrm{\&} 0.5 \mathrm{~km} \mathrm{~N}$ of Delta, $R$. Riviere 328 (MO); mpio. San Juan del Norte, Res. IndioMaíz, Cerro el Gigante, $R$. Rueda, I. Coronado \& N. Tercero 444 (HULE, MO); Cerro el Diablo, R. Rueda, I. Coronado, O. Aráuz \& F. Flores 5434 (HULE, MO); Cerro Canta Gallo, R. Rueda, I. Coronado, W. Velásquez \& Y. Rui 8594 (HULE, MO).

Acknowledgments. We thank the curators of the CR, DUKE, F, INB, and PTBG herbaria for access to specimens; the Museo Nacional de Costa Rica, INBio, and the grant "Desarrollando capacidades y compartiendo tecnología para la gestión de la biodiversidad en Centroamérica" of the Norwegian Ministry of Foreign Affairs for support and logistical help for travel by the first author; M. Grayum and D. H. Lorence for helpful comments; and R. Magill and O. M. Montiel for significant facilitation of this work.

\section{Literature Cited}

Bawa, K. S. \& J. H. Beach. 1983. Self-incompatibility systems in the Rubiaceae of a lowland wet tropical forest. Amer. J. Bot. 70: 1281-1288.

Beach, J. H. 1983. Posoqueria latifolia (Boca de Vieja, Guayaba de Mico, Fruta de Mono). Pp. 307-308 in D. H. Janzen (editor), Costa Rican Natural History. University of Chicago Press, Chicago.

Burger, W. C. \& C. M. Taylor. 1993. Flora Costaricensis. Family \#202 Rubiaceae. Fieldiana, Bot. n.s. 33: 1-333.

Cortés B. R., P. G. Delprete \& T. J. Motley. 2009. Phylogenetic placement of the tribe Retiniphylleae among the subfamily Ixoroideae (Rubiaceae). Ann. Missouri Bot. Gard. 96: 61-67.

Delprete, P. G. 2009. Taxonomic history, morphology, and reproductive biology of the tribe Posoquerieae (Rubiaceae, Ixoroideae). Ann. Missouri Bot. Gard. 96: 79-89.

Delprete, P. G., L. B. Smith \& R. B. Klein. 2004. Rubiáceas, Vol. I, Gêneros de A-G: 1. Alseis até 19. Galium. Pp. 1-344 in A. Reis (editor), Flora Ilustrada Catarinense. Herbário "Barbosa Rodrigues," Santa Catarina.

Dwyer, J. D. 1980. Rubiaceae. In R. E. Woodson Jr., R. W. Schery \& collaborators (editors), Flora of Panama-Part IX. Ann. Missouri Bot. Gard. 67: 1-522.

ESRI (Environmental Systems Research Institute). 1999. ArcView GIS 3.2. ESRI, Redlands, California.
Gentry, A. H. 1982. Patterns of Neotropical plant species diversity. Evol. Biol. 15: 1-84.

Hutchinson, J. 1915. New or noteworthy plants, Posoqueria densiflora. Gard. Chron., ser. 3, 57: 306-307.

IUCN. 2001. IUCN Red List Categories and Criteria, Version 3.1. Prepared by the IUCN Species Survival Commission. IUCN, Gland, Switzerland, and Cambridge, United Kingdom.

IUCN Standards and Petitions Working Group. 2008. Guidelines for Using the IUCN Red List Categories and Criteria, Version 7.0. IUCN, Gland, Switzerland, and Cambridge, United Kingdom.

Macias, L. 1988. Revisão Taxonômica do Gênero Posoqueria Aubl. (Rubiaceae). Master's Thesis, Universidade Estadual de Campinas, São Paulo.

Macias, L. \& L. S. Kinoshita. 2003. A new species of Posoqueria from Habia, Brazil. Novon 13: 206-208.

Moat, J. 2007. Conservation assessment tools extension for ArcView 3.x, version 1.2. GIS Unit, Royal Botanic Gardens, Kew, Richmond. <http://www.kew.org/gis/ projects/cats/catsdoc.pdf $>$, accessed 10 January 2011.

Puff, C., A. Igersheim, R. Buchner \& U. Rohrhojer. 1995. The united stamens of Rubiaceae. Morphology, anatomy; their role in pollination ecology. Ann. Missouri Bot. Gard. 82: $357-382$.

Robbrecht, E. \& J.-F. Manen. 2006. The major evolutionary lineages of the coffee family (Rubiaceae, angiosperms). Combined analysis (nDNA and cpDNA) to infer the position of Coptosapelta and Luculia, and supertree construction based on $r b c L, r p s 16, \operatorname{trnL-trnF}$, and $a t p B-$ $r b c L$ data. A new classification in two subfamilies, Cinchonoideae and Rubioideae. Syst. Geogr. Pl. 76: 85-146.

Rova, J. H. E., P. G. Delprete, L. Andersson \& V. A. Albert. 2002. A trnL-F cpDNA sequence study of the Condamineeae-Rondeletieae-Sipaneeae complex with implications of the phylogeny of the Rubiaceae. Amer. J. Bot. 89: 145-159.

Schulman, L., T. Toivonen \& K. Ruokolainan. 2007. Analysing botanical collecting effort in Amazonia and correcting for it in species range estimation. J. Biogeogr. 34: 1388-1399.

Steyermark, J. A. 1967. Posoqueria. In B. Maguire \& collaborators (editors), The Botany of the Guayana Highland-Part VII. Mem. New York Bot. Gard. 17: $322-333$.

Steyermark, J. A. 1974. Rubiaceae. In T. Lasser (editor), Flora de Venezuela, 9(1-3): 1-2070. Instituto Botánico, Dirección de Recursos Naturales Renovables, Ministerio de Agricultura y Cría, Caracas.

Taylor, C. M. 2001. Rubiaceae. Pp. 2206-2284 in W. D. Stevens, C. Ulloa Ulloa, A. Pool \& O. M. Montiel (editors), Flora de Nicaragua. Monogr. Syst. Bot. Missouri Bot. Gard. 85(3).

Taylor, C. M. \& R. Cortés-Ballén. 1999. Una especie nueva de Posoqueria (Rubiaceae) de la guyana colombiana. Novon 9: 428-430.

Taylor, C. M., J. A. Steyermark, P. G. Delprete, A. Vincentini, R. Cortés, D. Zappi, C. Persson, C. Bestetti Costa \& E. Araujo da Anunciação. 2004. Rubiaceae. Pp. 497-847 in P. E. Berry, K. Yatskievych \& B. K. Holst (editors), Flora of the Venezuelan Guayana, Vol. 8. Missouri Botanical Garden Press, St. Louis. 


\section{$2 \mathrm{BHL}$ Biodiversity Heritage Library}

Taylor, Charlotte M., Hammel, Barry, and Gereau, Roy E. 2011. "Rubiacearum Americanarum Magna Hama Pars XXVII: Six New Species and a New Taxonomic View of Posoqueria." Novon a journal of botanical nomenclature from the Missouri Botanical Garden 21(1), 118-132.

https://doi.org/10.3417/2009127.

View This Item Online: https://www.biodiversitylibrary.org/item/180102

DOI: https://doi.org/10.3417/2009127

Permalink: https://www.biodiversitylibrary.org/partpdf/218464

\section{Holding Institution}

Missouri Botanical Garden, Peter H. Raven Library

\section{Sponsored by}

Missouri Botanical Garden

\section{Copyright \& Reuse}

Copyright Status: Permission to digitize granted by rights holder

Rights: https://www.biodiversitylibrary.org/permissions

This document was created from content at the Biodiversity Heritage Library, the world's largest open access digital library for biodiversity literature and archives. Visit BHL at https://www.biodiversitylibrary.org. 